\title{
The Transformation of the Party Newspaper and the Construction of Modern Communication Ability
}

\author{
Liya Yao \\ Jilin Engineering Normal University, Changchun, Jilin \\ 415356818@qq.com
}

\begin{abstract}
Keywords: The transformation of the party newspaper; Modern communication; Internet; Ability construction
\end{abstract}

\begin{abstract}
In recent years, a new situation has emerged in the development of the newspaper industry. The speed of the development of the party newspaper has been obviously accelerated, and it has surpassed the demand of urban newspapers. From the original loss to the current favor, the party newspaper has become a "new darling". Then some people will ask: "the party newspaper has developed so well, why should we have to transform it?" In the final analysis, it is determined by the modern information technology and the construction of modern communication ability. The continuous development of the new media, represented by the Internet, has brought a lot of pressure on the traditional media industry. In order to better comply with the trend of development of the times, the construction of the party newspaper should seize the opportunity to make full use of its advantages, emphasize strategies, seize opportunities and achieve better transformation with internet thinking. In this paper, the author mainly explores the transformation of the party newspaper and the construction of modern communication ability in the new media environment.
\end{abstract}

\section{Introduction}

With the further deepening of economic globalization, China has already entered the era of full media. Under the influence of the Internet, people's life is more convenient, and the number of Internet users is increasing. The new media not only changes the way people live, but also changes the way people think. In this social background, accelerating the transformation of the party newspaper and the construction of modern communication ability has become an important subject for the construction and development of the party newspaper.

\section{There are Misunderstandings in the Transformation of the Party Newspaper and the Construction of Modern Communication Ability}

As early as 2014, general secretary Xi Jinping has emphasized in the "Guidance on the Promotion of Integration Development of the Traditional Media and Emerging Media": "we should focus on building an amount of new mainstream media that are diverse, advanced and competitive, and build a new media group that has strong strength and dissemination power, credibility and influence". In response to the call of general secretary Xi Jinping, a large amount of mainstream media invested a large amount of financial, material and human resources to carry out the media integration. In order to attract a new generation of readers, some party newspaper media try a variety of means, however, these means are simply the opening of micro-blog, WeChat clients, and the promotion of APP, etc. The original paper media is transferred to the new media platform, but this grafting type of knowledge transfer and a simple superposition of knowledge do not form effective interaction between the paper media and the new media. Media integration is not a simple addition, but a qualitative change on the basis of addition.

In addition, some party newspapers cater to readers in order to improve their reading volume and also they ignore their own values and functions in order to cater to the market, which is a misinterpretation of the party newspaper transformation. The party newspaper is the propaganda position of the Party and the government, and the surname of the party newspaper must be the Party. The public opinion in the party newspaper should reflect the will of the Party, safeguard the Party's 
authority, respond to the party's opinion, and form the national customs of loving and protecting the party in the whole society. Therefore, the party newspaper must firmly stand on its own position and cannot change its own value because of the intervention of the media. In the new period of social development, we should recognize the situation, grasp the situation and adapt to the situation, so that we can make the party newspaper become a tool for serving the Party and the people, and for the well-being of the people.

\section{Primary Exploration of the Transformation Path of the Party Newspaper}

The Advantages of the Party Newspaper. With the rapid development of the Internet today, the party newspaper is facing the impact of the Internet, and we are fully aware of this problem. After a series of structural adjustments and integration of resources, the party newspaper renews the vigor and vitality. From the development of recent years, the party newspaper still occupies the main position. The party newspaper makes progress and increases while enduring stability, so it is still full of vigor and vitality in the new period. The analysis is mainly from the following aspects:

The first one is the advantages of the mainstream media of the party newspaper. The party newspaper is a tool to propagate the Party's policy and line program, and still has its own advantages in the Internet age. This advantage is not only a political advantage, but also a policy advantage.

The second one is the incentive effect of the party newspaper. As the propaganda material of the Party, the party newspaper is a good medicine to prevent people from falling down in the spirit. When people read the party newspaper, they should find their own gap by contrast. Only if we read every day, accumulate over time and persist, we can understand the important contents in the party newspaper deeply, engrave valuable experience in our mind, and learn from it constantly.

The third one is the richness of the content of the party newspaper. The rich content of the party newspaper is a living textbook, transmitting the voice of the Party and transmitting the positive energy. Not only party members and cadres, but each of our socialist citizens should learn the party newspaper consciously to truly combine learning and thinking. On the basis of reading and understanding the content of the party newspaper, we can learn to reflect on the party newspaper, make it better and better, and close the distance between the Party and the people.

The fourth one is the adaptability of the party newspaper in the times. From slash-and-burn cultivation to all media information era, the ways of production and the habit of thinking of people have changed dramatically. From the paper media to the multimedia electronic age, the way of information dissemination has changed greatly. From the beginning of its emergence to the present, the newspaper industry has undergone many changes, throwing away pen and paper, and the people have entered the era of light and electricity. We are not only the witnesses of the changes of the times, but also the practitioners.

Primary Exploration of the Transformation of Party Newspaper under the Background of Internet. Looking at the development of the newspaper industry in China, after the newspaper industry was neglected by times, it began to spare no effort to catch up and accelerate the transformation. As the mainstream media, the party newspaper is an important form of value transmission and national public opinion. The party newspaper has the characteristics and advantages that other newspapers can not reach, such as political superiority, cultural advantage, talent advantage, market adaptation advantage, etc. In the process of transformation, it combines with the Internet to form a powerful combination. According to incomplete statistics, up to now, the Internet application rate in China has reached more than $60 \%$, which marks that most people in China have entered the age of the Internet. The new media affects people all the time, and occupies their spare time and communication time. The advantages of the traditional media no longer exist, and the new media, with its unique advantages, is deeply loved by the audiences. In the new media environment, the transformation of the party newspaper is actually a creation of paper media. By the impact of new media, more and people use electronic devices to watch the news, and the audience of the print media is less and less. The party newspaper is an important medium of information transmission and value dissemination of the Party and the government and an important 
form of public opinion in the country. In order to ensure the mainstream media status of party newspapers and highlight the discourse power of party newspapers, we should speed up the transformation of party newspapers and the construction of the modern communication ability, so that people can firmly grasp the socialist core values and promote the integration of traditional media and modern media.

The Internet has its advantages, such as innovation, wide channels of communication, wide range of audience and so on. While making full use of the political advantages, the party newspaper combines the advantages of the Internet technology. On the road of integration and development, the road of innovation and development is the icing on the cake for the future development of the party newspaper.

\section{Ways of Building Modern Communication Ability}

The media integration emphasized by general secretary Xi Jinping is, in essence, building the ability of modern communication. The modern communication ability is based on the Internet, and the main purpose of media integration is to occupy the Internet position.

Taking the Government as the Support and Accelerating the Construction of Communication Ability. The subsidies of the government at all levels to the newspaper industry is for the purpose of better integration of development, transformation and development, and strengthening the construction of communication ability. We should make clear the goal, strive for the development in a steady way, learn from the advanced experience of the excellent media at home and abroad, adhere to the long-term goal of reform and opening up, further deepen the reform, constantly improve the ability and influence of communication in the process of the new media integration, and create newspaper industry media that match the times and informatization.

Taking Innovation as the Motivation and Accelerating the Construction of Communication Ability. Under the new social situation, the party newspaper should still firmly adhere to the responsibility and mission, and actively explore the way of reform and innovation. Innovation is an inexhaustible motivation for the progress and development of the industry, and the scientific development and innovation development are the driving force on the road of reform. With the advent of the new media era, the development of the party newspaper faces opportunities and challenges. Each party newspaper group has paid great attention to the transformation of media integration. On the basis of the actual market survey, the leaders personally guide them, which has a strong impetus for the transformation and development of the party newspaper. In the new media era, the party newspaper should innovate and some newspaper industry groups should strive to create a "two ends, one network and one center" mode and change the status of the newspaper industry in a short time. According to the readers' interest and habits, the clients developed by the newspaper industry group should make the top-class APP based on the paper media.

Innovating Management Mode. The operation mode of the corporatization and marketization is the new way of the sustainable development of the party newspaper under the condition of the socialist market economy. The company is a parent and a legal person, as well as a sponsor and an investor. The newspaper industry group holds controlling interest, and gives full play to the advantages of the news class APP with the commercial model of traffic and advertising. In terms of content, it attaches importance to authority, exclusivity, depth and connotation, emphasizes video reporting, develops with distinct and distinctive content and the operation way of closely following the pace of the times and does a good job of service in the related fields. The innovative way of management is a new step in the development of media integration.

\section{The Future Prospects of the Transformation of the Party Newspaper and the Construction of Modern Communication Ability}

In order to adapt to the development of the times, the party newspaper is also in the process of continuous transformation and innovation. Two kinds of media should be done in the transformation of the party newspaper, one is the traditional media and the other is the new media. From the 
development of the party itself, we must adhere to the principles that do not blindly follow the instructions of the leadership, do not blindly trust the book knowledge, but see the actual situation to determine the methods. We should look at the current system and the reality of social development with the vision of development, so as to achieve integration development and form a new type of development format. Also we should base the traditional media, take root in the reality of social development in our own area, and accelerate the pace of innovation and development. The future prospects of the transformation of the party newspaper should make clear the following questions: The first one is that the property of the party newspaper will not change in the new period. The second one is that on the basis of expanding the new readers, the target group of the party newspaper should be stabilized. The third one is that in the new media environment, the party newspaper should adapt to new technology and integrate new technology.

\section{Conclusions}

The continuous development of the new media, represented by the Internet, has brought a lot of pressure on the traditional media industry. In order to better comply with the trend of development of the times, the construction of the party newspaper should seize the opportunity to make full use of its advantages, emphasize strategies, seize opportunities and achieve better transformation with internet thinking.

\section{Acknowledgements}

The periodic research results of "13th Five-Year" planning project of education science in Jilin "Research on the Improvement of Local Industry Ability of Scientific Research Service in Application-Oriented Universities in Jilin" (ZD17134)

\section{References}

[1] Z.A.Zhang: The Path Choice of the Integration and Transformation of the Party Newspaper at the Grass-Roots Level[J], China Newspaper Industry, 2015(23):7-7.(In Chinese)

[2] A.H.Wu: The Strategic Transformation of the Party Newspaper in the Full Media Era[J], China City Journalist, 2012(11):12-13.(In Chinese)

[3] X.Q.gu: The Transformation Analysis of the Party Newspaper under the Background of the New Media[J], News World, 2016(10):54-56.(In Chinese)

[4] J.W.Tang and J.D.Wang: The Transformation Thinking and Countermeasures of Local Party Newspaper under the New Media Pattern[J], China City Journalist, 2016(8):34-35.(In Chinese)

[5] C.L.Luo: Promoting the Transformation of the Party Newspaper with Digital Publishing[J], Media, 2013(9):24-26.(In Chinese)

[6] X.J.Yuan and Y.Zhou: A Brief Introduction of the Research on the Transformation and Upgrading of the Party Newspaper and the Scientific Development under the Media Convergence[J], Theory and Practice of Contemporary Education, 2014,6(2):174-176.(In Chinese)

[7] L.Ding: Traditional Media and New Media are Integrated and Developed to Promote the Transformation and Upgrading of the Party Newspaper[J], Journal News Research, 2016,7(17).(In Chinese)

[8] J.H.Gao: Thinking on the Transformation and Development of the Party Newspaper in the City[J], China City Journalist, 2016(6):9-10.(In Chinese)

[9] J.Shen: How to Realize the Transfer of Modern Communication Mode by the Party Newspaper Weekly[J], Media Observer, 2007(2):62-62.(In Chinese)

[10]Z.S.Jiang: The Reform and Innovation of the Party Newspaper: Transforming to the Modern Mainstream Media[J], News Front, 2009(3):30-31.(In Chinese) 